\title{
Tcnlp/Crzlp, a calcineurin-dependent transcription factor that differentially regulates gene expression in Saccharomyces cerevisiae
}

\author{
Dina P. Matheos, Tami J. Kingsbury, U. Salma Ahsan, and Kyle W. Cunningham ${ }^{1}$ \\ Department of Biology, Johns Hopkins University, Baltimore, M aryland 21218 USA
}

\begin{abstract}
$\mathrm{Ca}^{2+}$ signals regulate gene expression in animal and yeast cells through mechanisms involving calcineurin, a protein phosphatase activated by binding $\mathrm{Ca}^{2+}$ and calmodulin. Tcnlp, also named $\mathrm{Crzlp}$, was identified as a transcription factor in yeast required for the calcineurin-dependent induction of PMC 1, PMR 1, PMR 2A, and FK S2 which confer tolerance to high $\mathrm{Ca}^{2+}, \mathrm{Mn}^{2+}, \mathrm{Na}^{+}$, and cell wall damage, respectively. Tcnlp was not required for other calcineurin-dependent processes, such as inhibition of a vacuolar $\mathrm{H}^{+} / \mathrm{Ca}^{2+}$ exchanger and inhibition of a pheromone-stimulated $\mathrm{Ca}^{2+}$ uptake system, suggesting that $\mathrm{Tcnlp}$ functions downstream of calcineurin on a branch of the calcium signaling pathway leading to gene expression. Tcnlp contains three zinc finger motifs at its carboxyl terminus resembling the DNA-binding domains of Zif268, Swi5p, and other transcription factors. When fused to the transcription activation domain of Gallp, the carboxy terminal domain of Tcnlp directed strong calcineurin-independent expression of PMC 1-IacZ and other target genes. The amino-terminal domain of Tcnlp was found to function as a calcineurin-dependent transcription activation domain when fused to the DNA-binding domain of Gal4p. This amino-terminal domain also formed $\mathrm{Ca}^{2+}$-dependent and FK506-sensitive interactions with calcineurin in the yeast two-hybrid assay. These findings suggest that Tcnlp functions as a calcineurin-dependent transcription factor. Interestingly, induction of Tcnlp-dependent genes was found to be differentially controlled in response to physiological $\mathrm{Ca}^{2+}$ signals generated by treatment with mating pheromone and high salt. We propose that different promoters are sensitive to variations in the strength of $\mathrm{Ca}^{2+}$ signals generated by these stimuli and to effects of other signaling pathways.
\end{abstract}

[Key Words: Calcineurin; transcription; signal transduction; calcium]

Calcium signaling mechanisms are employed by all eukaryotic cells to regulate gene expression and a wide range of other cellular processes. During excitation of neurons, for example, calmodulin-dependent protein kinases differentially activate the transcription factors CAM $P$ response element binding (CREB) and serum response factor (SRF) in response to subtle variations in the source or type of $\mathrm{Ca}^{2+}$ signal generated (for review, see Ginty 1997). C $\mathrm{Ca}^{2+}$ signals can al so regulate gene expression through the calmodulin-dependent protein phosphatase known as calcineurin. In human T cells, for example, calcineurin binds and dephosphorylates members of the NFAT family of transcription factors triggering their nuclear localization and stimulating gene expression (for review, see Rao et al. 1997). The immunosuppressive compounds cycl osporin A and FK 506 are known as potent inhibitors of calcineurin (see Schreiber and

${ }^{1}$ Corresponding author.

E-MAIL kwc@ihunix.hcf.jhu.edu; FAX (410) 516-5213.
Crabtree 1992) and have been used to reveal essential roles of calcineurin in T-cell activation and presumably in other cell types (see Collier 1990).

The budding yeast Saccharomyces cerevisiae maintains functional homologs of calmodulin (Davis et al. 1986), calcineurin (Cyert et al. 1991; Kuno et al. 1991; Liu et al. 1991; Cyert and Thorner 1992; Ye and Bretscher 1992) and calmodulin-dependent protein kinases (Ohya et al. 1991; Pausch et al. 1991). Although signaling by these factors is not required for vegetative growth (Geiser et al. 1991), it is required for longterm survival of cells responding to high doses of mating pheromones (M oser et al. 1996). M ating pheromones are diffusible peptide hormones secreted by the two hapl oid cell types that serve to prepare each other for sexual conjugation (for review, see Sprague and Thorner 1992). Binding of pheromones to specific receptors on the cell surface triggers a signaling cascade involving trimeric G proteins, a mitogen-activated protein (MAP) kinase cascade, and other associated factors that prepare the cell for conjugation. The effects of pheromone signaling can be 
categorized loosely into early and late responses, both of which are required for efficient mating. The early responses include induction of mating-specific genes and arrest in $G_{1}$ phase of the cell division cycle. Late effects of pheromone signaling occur after prolonged intensive stimulation and include changes in cell morphology and polarity, down-regulation and desensitization of the signaling machinery, and resumption of mitotic growth. After at least $30 \mathrm{~min}$ of intensive pheromone signaling, the rate of $\mathrm{Ca}^{2+}$ influx is enhanced (Ohsumi and Anraku 1985) leading to an elevation of cytosolic-free $\mathrm{Ca}^{2+}$ (lida et al. 1990; N akajima-Shimada et al. 1991) and activation of the cal modulin-dependent kinases and calcineurin, which independently promote cell survival (Moser et al. 1996). The molecular mechanisms through which pheromone signaling stimulates $\mathrm{Ca}^{2+}$ influx and calcium signal ing promotes cell survival are starting to be elucidated (lida et al. 1994; Withee et al . 1997).

The cal cium signaling pathway of yeast has also been implicated as a regulator of cation homeostasis. $\mathrm{Ca}^{2+}$ calmodulin appears to bind and stimulate members of the Pmr2p family of P-type ion pumps (Wieland et al. 1995), which are involved in $\mathrm{N} \mathrm{a}^{+}$and $\mathrm{Li}^{+}$efflux (Rudol ph et al. 1989; Haro et al. 1991). Additionally, maximal induction of the PMR2A/ENA 1 gene in response to high environmental salt requires calcineurin activation by $\mathrm{Ca}^{2+} /$ calmodulin (Garciadeblas et al. 1993; Cunningham and Fink 1996). Calcineurin may further promote $\mathrm{N} \mathrm{a}^{+}$ tolerance through other mechanisms ( $\mathrm{N}$ akamura et al. 1993; Mendoza et al. 1994; Hirata et al. 1995; Danielsson et al . 1996; Mendoza et al. 1996) and al so promotes $\mathrm{M} \mathrm{n}^{2+}$ tolerance (Farcasanu et al. 1995; Cunningham and Fink 1996; Pozos et al. 1996). In high $\mathrm{Ca}^{2+}$ conditions, activation of calcineurin by $\mathrm{Ca}^{2+} /$ calmodulin induces the expression of PMCl and PMR1 (Cunningham and Fink 1996), which respectively encode $\mathrm{Ca}^{2+}$-pumping ATPases in the vacuole and Golgi complex (Rudolph et al. 1989; Antebi and Fink 1992; Cunningham and Fink 1994; Sorin et al. 1997). Finally, calcineurin activation appears to strongly inhibit the function of Vcxlp (Cunningham and Fink 1996), a vacuolar $\mathrm{H}^{+} / \mathrm{Ca}^{2+}$ exchanger also known as Humlp (Pozos et al. 1996). Additional roles of calcineurin have also been detected in mutants deficient in either the vacuolar or plasma membrane $\mathrm{H}^{+}$ ATPases (Hemenway et al. 1995; Tanida et al. 1995; $\mathrm{N}$ ass et al. 1997). These transcriptional and post-translational effects of calcineurin may be mediated by a number of unidentified factors.

This work aims to identify factors that mediate the cal cineurin-dependent induction of PMC1 and to determine their roles in other calcineurin-dependent processes. Through genetic and molecular approaches, we have identified Tcnlp, also called Crzlp (Stathopoulos and Cyert, this issue), as a specific transcription factor required for calcineurin-dependent induction of all the previously reported target genes plus TCN 1 itself. We also show that most Tcnlp-dependent genes can be differentially induced based on mechanisms sensitive to both strength of $\mathrm{Ca}^{2+}$ signals and other regulatory inputs.

\section{Results \\ Differential expression of calcineurin-dependent reporter genes in response to various physiological stimuli}

Previous work has demonstrated critical roles for calcineurin in the induction of PMC1, PMR1, PMR2A, and FKS2 in response to at least one of the three physiological conditions that generate $\mathrm{Ca}^{2+}$ signals (Garciadeblas et al. 1993; M azur et al. 1995; Cunningham and Fink 1996). Treatment with high salt causes calcineurin-dependent induction of PMR2A, and treatment with high amounts of mating pheromone concentrations leads to induction of FKS2. Growth in high $\mathrm{Ca}^{2+}$ conditions induces all four genes. To determine whether all the calcineurin-dependent genes respond to these types of $\mathrm{Ca}^{2+}$ signals, we examined expression patterns of various lac $Z$ reporter genes with and without FK506, a potent inhibitor of calcineurin in yeast (Foor et al. 1992). Treatment with high salt $(750 \mathrm{~mm} \mathrm{NaCl})$ caused calcineurin-dependent (FK506-sensitive) induction of PMR2A-lacZ but not PMC1-lacZ or FKS2-lacZ. Similarly, treatment with high pheromone (20 $\mu \mathrm{M} \alpha$-mating factor) stimulated expression of theFKS2-lacZ reporter gene by a calcineurindependent mechanism but caused little or no calcineurin-dependent induction of either PMC1-lacZ or PMR2A-lacZ (Fig. 1). Thus, different physiological generators of $\mathrm{Ca}^{2+}$ signals can produce distinct transcriptional responses in yeast as in neurons (for review, see Ginty 1997).

To investigate this phenomenon further, the effects of high salt and pheromone on gene expressi on were examined during growth in high $\mathrm{Ca}^{2+}$ medium. High salt treatment blocked the normal calcineurin-dependent induction of PMC1-lacZ and FKS2-lacZ but not PMR2Alac $Z$. Treatment with pheromone blocked the normal cal cineurin-dependent induction ofPM R2A-lacZ but not FKS2-IacZ or PMC 1-lacZ. These results indicate that in addition to generating $\mathrm{Ca}^{2+}$ signals that activate calcineurin, the response to high salt inhibits expression of both PMC1 and FKS2, whereas the pheromone response inhibits expression of PMR2A. One explanation for why pheromone treatment fails to modulate PMC1-lacZ expression emerges from the identification and characterization of a calcineurin-dependent transcription factor.

TCN 1 encodes a zinc finger protein required for calcineurin-dependent induction of PM C1-lacZ

Differential expression of calcineurin-dependent genes may be accomplished using different sets of transcription factors or possibly using the same transcription factors and modulating their effectiveness toward specific targets. To help distinguish these possibilities, we sought to identify and characterize the calcineurin-dependent transcription factors regulating PMC1. A sensitive colony color assay was used to identify mutants of strains DMY62 and DMY63 (Table 1) that failed to express PMC1-lacZ during growth in high $\mathrm{Ca}^{2+}$ conditions 


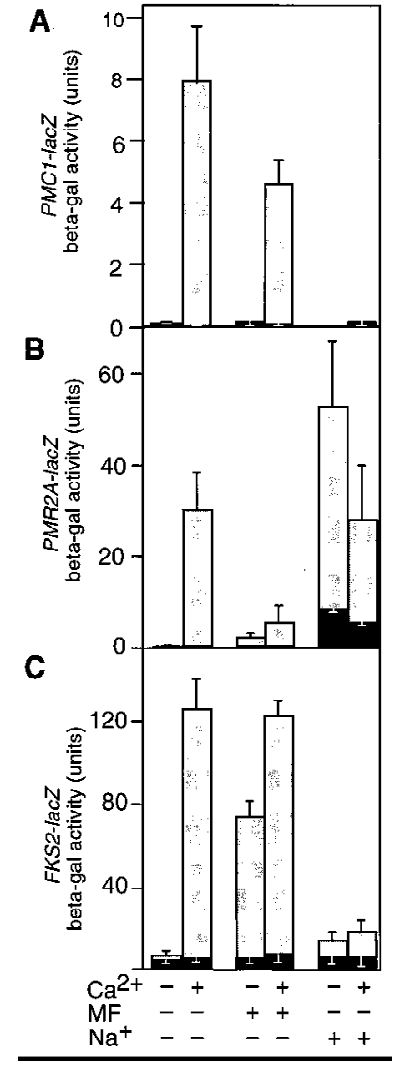

Figure 1. Treatments with $\mathrm{CaCl}_{2}$, pheromone, or high salt generate $\mathrm{Ca}^{2+}$ signals that differentially induce calcineurin-dependent reporter genes. Wild-type yeast (strain W303-1A) was transformed with either plasmid pKC 190 carrying PMC 1-lacZ (A), plasmid pKC201 carrying PMR2A-lacZ (B), or plasmid pDM 5 containing FKS2-lacZ (C), grown to mid-log phase and treated for $4 \mathrm{hr}$ at $30^{\circ} \mathrm{C}$ in Y PD (pH 5.5) medium with $0.2 \mu \mathrm{g} / \mathrm{ml}$ of FK506 (solid bars) or without FK506 (shaded bars) with the additional supplements of $\mathrm{Ca}^{2+}(100 \mathrm{~mm} \mathrm{CaCl})$, pheromone (20 $\mu \mathrm{g} / \mathrm{ml}), \mathrm{Na}^{+}(750 \mathrm{~mm} \mathrm{NaCl})$, or combinations thereof as indicated at the base of the plot. Each bar represents the average of three independent determinations of accumulated $\beta$-galactosidase activity ( \pm S.D.).

(see M aterials and M ethods). Thirty-one independent recessive mutants were recovered from this genetic screen and placed into just three complementation groups. All members of the first group (six isolates) behaved like mutants lacking the regulatory $B$ subunit of cal cineurin (Cunningham and Fink 1994) and were allelic to cnb1 null mutants. As expected from earlier studies, no members of the second group (11 isolates) or third group (14 isolates) represented mutant alleles of calmodulin or the catalytic A subunit of calcineurin and, instead, defined two new components of the calcium signaling pathway. All members of the second group were complemented by Iow copy plasmids carrying MSN5/STE21, a previously characterized gene that functions in several processes unrelated to cal cium signaling (Akada et al. 1996; P.M. Alepuz, D.P. Mathews, K.W. Cunningham, and F. Estruch, in prep). M embers of the third group were comple- mented by plasmids carrying YNL027w, a previously uncharacterized gene on chromosome XIV, which we have named TCN 1 for target of cal cineurin.

The predicted 678-amino-acid product of TCN1 contains three $\mathrm{C} 2 \mathrm{H} 2$-type zinc finger motifs at the carboxyl terminus that strongly resemble the DNA-binding domains of numerous transcriptional regulators such as Swi5p from yeast and Zif268/early growth response (EGR)-1/Krox-24 from mammals (Fig. 2B). Outsi de of the zinc finger domain, Tcnlp shows no obvious sequence similarity to any proteins in current databases but contains sequence features found in many other transcriptional regulators, such as three acidic regions (net charges of $-7,-23$, and -10 ) separated by a glutaminerich domain (residues 115-140) and a highly basic region (net charge of +13 , residues 398-443) rich in serine and threonine residues (Fig. 2A). These sequence features suggest that $T c n 1 p$ may function as a specific transcriptional activator in the calcium signaling pathway.

Distinct domains of Tcnlp interact specifically with calcineurin

T wo functional domains of T cn1p were defined by analysis of protein fusions constructed with the Gal $4 p$ transcription factor. Fusion of the carboxy-terminal zinc finger regi on of Tcn1p (residues 463-678) with the transcriptional activation domain of Gal $4 p$ yielded a functional hybrid protein that strongly induced PMC1-lacZ expression relative to controls in a fashion independent of $\mathrm{Ca}^{2+}$ and insensitive to FK506 (Fig. 3A). This constitutive $\operatorname{Ton} 1(C):: G a l 4(A D)$ hybrid protein did not induce expression of reporter genes that are normally unresponsive to $\mathrm{Ca}^{2+}$ signals, such as GAL1-lacZ or CYC1-lacZ but stimulated expression of PMR2A-lacZ and FKS2lacZ (data not shown). These results show that the carboxy-terminal zinc finger domain of Tcnlp retains the ability to form promoter-specific interactions.

The amino-terminal region of Tcnlp contains a transcriptional activation domain responsive to calcineurin because fusion of residues 11-460 with the DN A-binding domain of $\mathrm{Gal} 4 \mathrm{p}$ resulted in a $\mathrm{Gal} 4(\mathrm{DB}): \mathrm{T} \mathrm{Cn} 1(\mathrm{~N})$ hybrid protein that conferred $\mathrm{Ca}^{2+}$-stimulated and FK506sensitive induction to a GAL1-lacZ reporter gene (Fig. 3B). To test whether the amino-terminal domain of Tcnlp interacts directly or indirectly with calcineurin, a two-hybrid experiment was performed using fusions be tween the amino-terminal domain of Tcnlp and the catalytic subunit of calcineurin encoded by the yeast CNA1 gene (Cyert et al. 1991). Expression of a functional Gal4(DB)::Cnal hybrid protein in which the DN A-binding domain of Gal $4 p$ was fused to calcineurin A failed to induce GAL1-lacZ in standard media or in me dia supplemented with $\mathrm{Ca}^{2+}$ or FK506 (Fig. 3D, right). Similarly, expression of a Tcn1(N)::Gal4(AD) hybrid protein, in which the activation domain of Gal $4 p$ was fused to the amino-terminal domain of Tcnlp, also exhibited no ability to induce GAL1-lacZ because this protein lacks the appropriate DN A-binding domain (Fig. $3 C$, left). Coexpression of both $\operatorname{Tcn} 1(\mathrm{~N}):: \mathrm{Gal} 4(\mathrm{AD})$ and 
Matheos et al.

Table 1. Yeast strains used in this study

\begin{tabular}{|c|c|c|}
\hline Strain & Genotype ${ }^{a}$ & Reference \\
\hline W303-1A & + & Wallis et al. (1989) \\
\hline YLIP179 & MAT $\alpha$ fksl::HIS3 & Mazur et al. (1995) \\
\hline YLIP183 & fks1::HIS3 & Mazur et al. (1995) \\
\hline K601 & + & W303-1A \\
\hline K473 & pmcl::LEU 2 & Cunningham and Fink (1994) \\
\hline K482 & MAT $\alpha$ pmc1::TRP1 & Cunningham and Fink (1994) \\
\hline K603 & cnb1::LEU 2 & Cunningham and Fink (1994) \\
\hline K605 & pmcl::TRP1 & Cunningham and Fink (1994) \\
\hline K633 & pmr2::HIS3 & Cunningham and Fink (1996) \\
\hline K661 & $\operatorname{vcx} 1 \Delta$ & Cunningham and Fink (1996) \\
\hline K665 & vcx1 $\Delta$ pmcl::TRP1 & Cunningham and Fink (1996) \\
\hline DMY 14 & $\operatorname{tcn} 1:: G 418$ & \\
\hline DMY 18 & tcn1::G418 pmc1::TRP1 & \\
\hline DMY 20 & $\operatorname{tcn} 1:: G 418$ vex1s & \\
\hline DMY 24 & tcn1::G418 vcx1s pmc1::TRP1 & \\
\hline DMY 44 & tcn::G418 pmr2::HIS3 & \\
\hline DMY 62 & pmc1::LEU2 PMC1-lacZ::U RA3 & \\
\hline DMY 63 & MAT $\alpha$ pmc1::TRP1 PMC1-lacZ::URA3 & \\
\hline Y $190^{\mathrm{b}}$ & gal4 gal80 GAL1-lacZ & Harpter et al. (1993) \\
\hline
\end{tabular}

${ }^{a}$ All strains except Y190 are isogenic to W303-1A (MATa ade2-1 can1-100 his3-11,15 leu2-3,112 trp1-1 ura3-1). Strain-specific genotypes are as indicated.

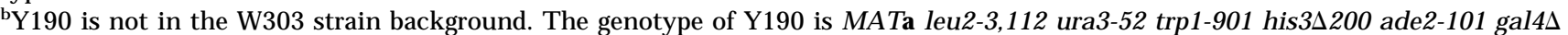

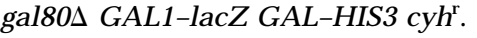

Gal4(DB)::Cnal restored induction of GAL1-lacZ by added $\mathrm{Ca}^{2+}$, which was completely inhibited by FK506 (Fig. 3D, left). Similar results were obtained when the carboxy-terminal autoinhibitory domain of calcineurin
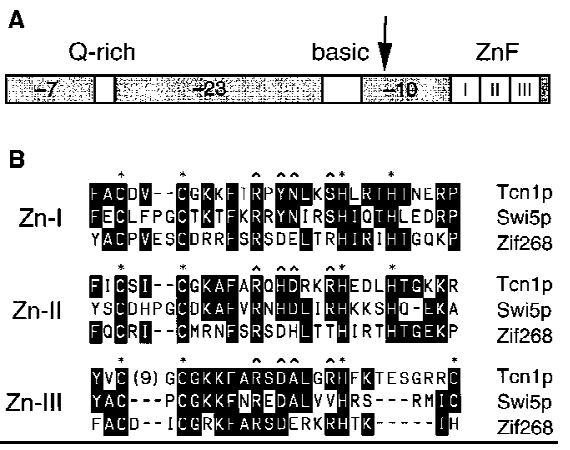

Figure 2. Sequence features of Tcnlp. (A) Predicted open reading frame of TCN1. Denoted are putative domains of Tcnlp: three acidic regions with net charges of $-7,-23$, and -10 , respectively; a Q-rich domain where 24 of 27 amino acid residues are glutamine; a basic region containing a net charge of +13 ; and three putative zinc fingers. The arrow indicates the division between the amino and carboxyl termini used to assay functionality of these two domains. (B) Multiple sequence alignment of the three zinc finger motifs from Tcnlp, and the transcription factors Swi5p (residues 550-632) from yeast (Stillman et al. 1988) and Zif268/EGR-1 (residues 287-367) from mammals (Lemai re et al . 1988). Residues conserved in at least two of the three sequences are boxed and highlighted. Residues that coordinate zinc ions (asterisks) and that contact DNA ( $\left.{ }^{\wedge}\right)$ in the crystal structure of Zif268 complexed with DN A (Pavletich and Pabo 1991) are indicated.
A was deleted from the hybrid protein (Fig. 3C, right). Overexpression of the hybrid proteins using high-copy pl asmid vectors increased the units but did not alter the patterns observed using the low-copy plasmids (data not shown). These results demonstrate that the amino-terminal domain of Tcnlp interacts functional ly with activated cal cineurin but not with inactive or FK506-inhibited calcineurin. Functional interactions detected using the two-hybrid assay usually reflect direct or indirect physical interactions (Fields and Sternglanz 1994).

\section{Targets of Tcn1p}

To determine whether Tcn1p mediates some or all of the effects of calcineurin on gene expression, both expression and function of the four known target genes were examined in a tcn 1 null mutant in which the TCN 1 coding sequence was deleted and repl aced (see M aterials and Methods). The tcn1 null mutant grew as well as wildtype strai ns in standard medium but completel y fai led to induce PMC1-lacZ in response to growth in high $\mathrm{Ca}^{2+}$ conditions ( $T$ able 2 , line 1 ). Furthermore, the normal calcineurin-dependent induction of reporter genes for PMR1, PMR2A, and FKS2 was completely abolished in the tcn 1 null mutant (Table 2, lines 2-4), whereas the control CYC1-lacZ reporter was not affected (line 5).

To confirm that PMC1, PMR1, PMR2A, and FKS2 are physiol ogical targets of $T \mathrm{cn} 1 \mathrm{p}$, the function of each gene was compared in wild-type and tcn 1 null mutants. The function of FKS2, for example, was measured qualitatively using a viability assay. Calcineurin-dependent expression of FKS2 is required for viability of cells lacking the homologous gene FKS1 (Parent et al. 1993; Eng et al. 
1994; Garrett-Engele et al . 1995). We found that like calcineurin, Tcnlp is also required for functional expres-
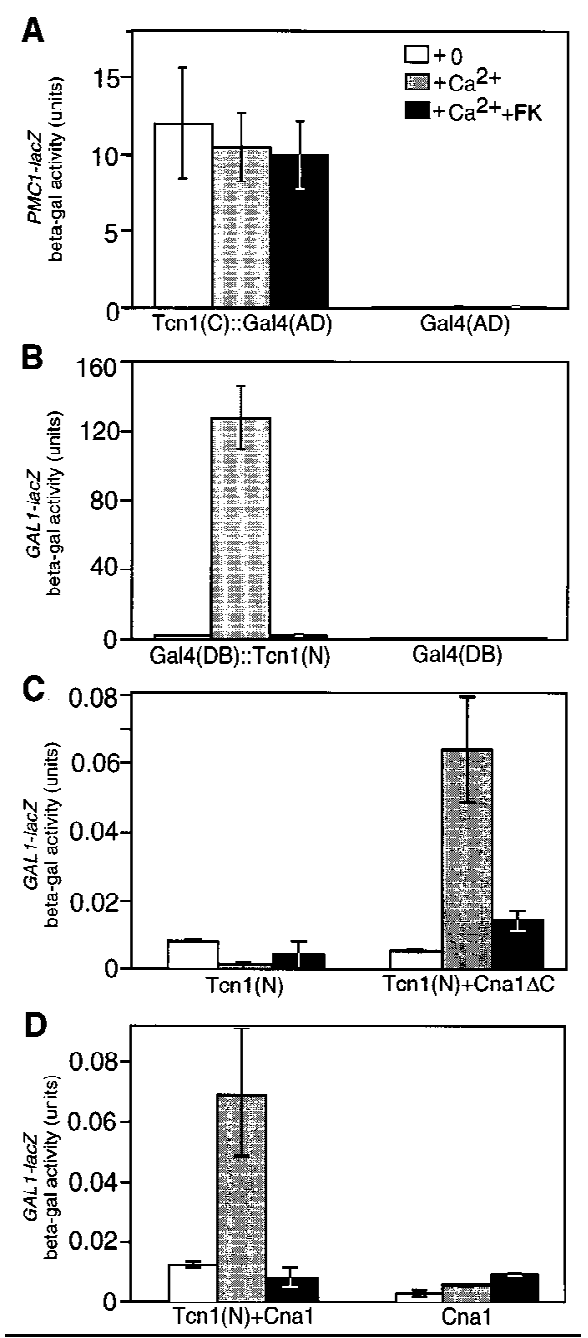

Figure 3. Functional domains of $T c n 1 p$ defined by fusions with Gal4p. (A) Expression of a PM C1-lacZ reporter gene on plasmid pKC190 in a ten1 null mutant (strain DMY 14) driven by either a Tcn1(C)::Gal4(AD) hybrid protein (plasmid pDM16) or a Gal 4(AD) fragment (plasmid pPC 86) as a control was measured after $4 \mathrm{hr}$ growth in YPD (pH 5.5) medium supplemented as indicated with $200 \mathrm{~mm} \mathrm{CaCl}$ and $0.2 \mu \mathrm{g} / \mathrm{ml}$ of FK506. Data are the averages of three independent transformants with standard deviation as indicated by error bars. Similar results were obtained using PMR2A-lacZ (pKC201) and FKS2-lacZ (pDM5) reporter genes. (B-D) Expression of a GAL1-lacZ reporter gene in a gal 4 gal 80 double mutant Y 190 (Harper et al. 1993) was measured as above using plasmids expressing the following hybrid proteins: (B) Gal 4(DB)::Tcn1(N) on plasmid pDM 15 or Gal 4(DB) on plasmid pPC 97; (C) Tcn1(N)::Gal4(AD) on plasmid pTJK27 with either Gal4(DB) on plasmid pPC97 or Gal4(DB)::Cnal $\Delta C$ on plasmid pKC116; (D) Gal4(DB)::Cnal on pKC 115 with either Tcn1(N)::Gal4(AD) on plasmid pTJK27 or Gal4(AD) on plasmid pPC 86. The results show the carboxyl terminus of Tcnlp interacts functionally with the promoter of PMC1 (A), whereas the amino-terminal region of T cnlp functions as both a cal cineurindependent transcription activation domain (B) and a calcineurin-interacting domain $(C, D)$. sion of FKS2 because all fks1 tcn 1 double mutants generated from 18 tetrads of a test cross (strain DMY 14 crossed with strain YLIP179) were inviable. The functions of PMR1, PMR2A, and PMC1 in tcn 1 mutants were assayed quantitatively using $\mathrm{Mn}^{2+}, \mathrm{Na}^{+}$, and $\mathrm{Ca}^{2+}$ tolerance tests, respectively. tcn1 mutants were significantly less tolerant than wild-type to these ions (Fig. 4). In the presence of FK506, wild-type strains and ton 1 mutants displayed approximately equal sensitivities to $\mathrm{Mn}^{2+}$, $\mathrm{N} \mathrm{a}^{+}$, and $\mathrm{Ca}^{2+}$, suggesting that $\mathrm{T} \mathrm{cn} 1 \mathrm{p}$ retains little or no activity in the absence of calcineurin function and that the two factors function in the same regulatory pathway.

The ion tolerance assays shown in Figure 4 also reveal functions of calcineurin that are independent of Tcn1p function. For example, addition of FK506 to tcn1 mutants and to pmr 2 tcn 1 double mutants causes a further reduction in $\mathrm{N} \mathrm{a}^{+}$tolerance (Fig. 4B), suggesting that calcineurin affects other $\mathrm{Na}^{+}$tolerance factors independently of Ton1p. In ton 1 null mutants, weak effects of calcineurin on PMR2A-lacZ expression were also evident depending on the growth conditions (T able 2, lines 4 and 8). Calcineurin also inhibits the function of Vcxlp in $\mathrm{Ca}^{2+}$ tolerance assays by a Tcnlp-independent mechanism because FK 506 addition increased $\mathrm{Ca}^{2+}$ tolerance of tcnl mutants, pmcl mutants, and pmcl ton 1 double mutants but only when VCX 1 was present. The finding that both pmcl ton 1 double mutants and pmrl ton 1 double mutants (not shown) are viable, whereas pmcl pmrl double mutants are inviable (Cunningham and Fink 1994), suggests that T cnlp-independent basal expression of either Pmclp or Pmrlp is sufficient for viability in standard media. In summary, the activity of Tcnlp on all known targets required calcineurin function, whereas the activity of calcineurin on at least two additional processes did not require Tcnlp function. These results suggest $T c n 1 p$ functions in a branch downstream of calcineurin in the cal cium signaling pathway leading to gene expression.

Roles of Tcnlp and calcineurin in response to pheromone

The $\mathrm{Ca}^{2+}$ signal generated in response to pheromone induces FKS2 through a cal cineurin-dependent mechanism (Mazur et al. 1995). Induction of an FKS2-lacZ reporter gene was also observed after treatment of wild-type MATa cells with pheromone, and this induction was almost completely dependent on calcineurin and Tcn1p (Table 2, line 7). Calcineurin function is required for several additional responses to pheromone treatment, including maintenance of cell viability during prolonged pheromone stimulation (Cyert et al. 1991; Cyert and Thorner 1992; Moser et al. 1996) and for changes in cell morphology (Withee et al. 1997). U sing si milar methods, we found that tcn1 null mutants were indistinguishable from wild type (data not shown), suggesting that these effects of cal cineurin are largely independent of T cnlp. Another effect of calcineurin during the pheromone response, feedback inhibition of $\mathrm{Ca}^{2+}$ uptake, is illustrated in Figure 5. After 4-hr treatment with $20 \mu \mathrm{m}$ pheromone, 
Table 2. Expression of reporter genes in wild-type and tcn1 mutants

\begin{tabular}{|c|c|c|c|c|c|c|c|c|c|}
\hline \multirow{3}{*}{ Plasmid } & \multirow{3}{*}{ Reporter } & \multicolumn{6}{|c|}{$\beta$-Galactosidase (units) } & \multicolumn{2}{|c|}{ Induction ratio } \\
\hline & & \multicolumn{3}{|c|}{ wild type } & \multicolumn{3}{|c|}{ ten1 mutant } & \multirow{2}{*}{$\frac{\text { wild type }}{(+\mathrm{Ca} /+\mathrm{Ca}+\mathrm{FK})}$} & \multirow{2}{*}{$\frac{\text { tcnl mutant }}{(+\mathrm{Ca} /+\mathrm{Ca}+\mathrm{FK})}$} \\
\hline & & to & $+\mathrm{Ca}$ & $+\mathrm{Ca}$ +FK & +0 & $+\mathrm{Ca}$ & $+\mathrm{Ca}+\mathrm{FK}$ & & \\
\hline 1. $\mathrm{pKC} 190$ & PMC1-lacZ & 0.2 & 19 & 0.1 & 0.1 & 0.1 & 0.1 & $270 \pm 90$ & $1.0 \pm 0.0$ \\
\hline 2. $\mathrm{pDM} 5$ & FKS2-IacZ & 10 & 232 & 10 & 4.0 & 5.0 & 5.0 & $21 \pm 7.0$ & $1.1 \pm 0.2$ \\
\hline 3. pKC199 & PMR1-lacZ & 11 & 28 & 12 & 5.0 & 5.0 & 6.0 & $2.3 \pm 0.6$ & $0.9 \pm 0.1$ \\
\hline 4. $\mathrm{pKC201}$ & PMR2A-IacZ & 0.1 & 59 & 4.5 & 0.1 & 0.1 & 0.8 & $14 \pm 3.6$ & $0.1 \pm 0.05$ \\
\hline 5. $\mathrm{pLG} \Delta 312$ & CYC1-IacZ & 424 & 483 & 466 & 358 & 483 & 415 & $1.0 \pm 0.1$ & $1.2 \pm 0.1$ \\
\hline \multirow[t]{2}{*}{ 6. $\mathrm{pDM} 7$} & TCN1-lacZ & 4.3 & 21 & 5.3 & 3.1 & 5.8 & 3.4 & $4.2 \pm 1.4$ & $1.7 \pm 0.4$ \\
\hline & & to & $+m f$ & $+m f+F K$ & to & $+\mathrm{mf}$ & $+m f+F K$ & $(+m f /+m f+F K)$ & $(+m f /+m f+F K)$ \\
\hline \multirow[t]{2}{*}{ 7. $\mathrm{pDM} 5$} & FKS2-IacZ & 39 & 166 & 50 & 17 & 26 & 24 & $3.4 \pm 0.6$ & $1.1 \pm 0.1$ \\
\hline & & to & $+\mathrm{Na}$ & $+\mathrm{Na}$ a+FK & +0 & $+\mathrm{Na}$ & $+\mathrm{Na}$ a+FK & $(+\mathrm{Na} /+\mathrm{N} a+F K)$ & $(+\mathrm{Na} /+\mathrm{Na}+\mathrm{FK})$ \\
\hline 8. pKC201 & PMR2A-lacZ & 3.3 & 163 & 39 & 1.4 & 53 & 38 & $4.2 \pm 0.4$ & $1.5 \pm 0.2$ \\
\hline
\end{tabular}

$\beta$-Gal actosi dase activity (units) was measured as described in M ethods and $M$ aterials after growth in YPD (pH 5.5) medium (lines 1-10) or YPD medium (lines 11,12 ) supplemented as indicated with water $(+0), 200 \mathrm{~mm} \mathrm{CaCl}(+\mathrm{Ca}), 20 \mu \mathrm{M} \alpha$-mating pheromone (+mf), 750 $\mathrm{mm} \mathrm{N} \mathrm{aCl}(+\mathrm{N} \mathrm{a})$, or $0.2 \mu \mathrm{g} / \mathrm{ml}$ of FK506 (+FK). The average of three independent transformants is shown in units; induction ratios were calculated separately for each transformant and then averaged ( \pm S.D.). The limit of detection for this experiment is 0.1 unit.

wild-type cells display a small increase in ${ }^{45} \mathrm{Ca}^{2+}$ accumulation. Inhibition of calcineurin by addition of FK506 greatly potentiated the effect of pheromone but had little or no effect on untreated wild-type cells. In a parallel experiment, a tcn1 null mutant showed a pattern of ${ }^{45} \mathrm{Ca}^{2+}$ uptake similar to wild type, indicating that $\mathrm{T} \mathrm{cn} 1 \mathrm{p}$ is not required for the apparent calcineurin-dependent feedback inhibition of $\mathrm{Ca}^{2+}$ uptake after pheromone treatment. Although Tcnlp becomes activated during the pheromone response and induces genes such as FKS2, it plays no obvious role in several other calcineurin-dependent processes including increased $\mathrm{Ca}^{2+}$ uptake, morphological changes, and cell survival.

\section{Dynamics of the calcium signaling pathway}

Complementation tests performed during the characterization of isolated ten 1 mutants, showed that heterozygous tcn $1 /$ TCN 1 diploids accumulated less than half as much $\beta$-galactosidase activity as homozygous TCN1/ TCN 1 diploids during growth in identical $\mathrm{Ca}^{2+}$ conditions (data not shown). This result implies that $\mathrm{T} c n 1 \mathrm{p}$ abundance may affect responsiveness to $\mathrm{Ca}^{2+}$ signals. Overexpression of Tcnlp by transforming a wild-type strain with the high dosage TCN1 plasmid (pLE66) resulted in higher induction of PMC1, FKS2, and PMR2A with lower doses of $\mathrm{Ca}^{2+}$ (Fig. 6B-D). For all reporters except FKS2, the maximum levels of expression were also el evated in the strain overexpressing Tcnlp (Fig. 6). A TCN 1-lacZ reporter gene was constructed (see Materials and M ethods) to determine whether $\mathrm{T} c n 1 \mathrm{p}$ levels might change in high $\mathrm{Ca}^{2+}$ conditions. In wild-type strains, TCN1-lacZ was induced about fourfold over basal levels by growth in high $\mathrm{Ca}^{2+}$ and this induction was largely dependent on calcineurin and T cnlp (Table
2, line 6) and highly sensitive to dosage of Tcnlp (Fig. 6A). The apparent autoregulation of Tcn1p combined with the varying sensitivities of each target promoter to $\mathrm{Tcn} 1 \mathrm{p}$ abundance and $\mathrm{Ca}^{2+}$ levels may permit differential gene expression in response to varying strength or intensity of $\mathrm{Ca}^{2+}$ signals.

Differential control of Tcnlp-dependent genes involves modulation of $\mathrm{Ca}^{2+}$ signal strength and other promoter-specific factors

One possible explanation for the failure of the calcium signaling pathway to induce PMC1-lacZ after pheromone treatment emerges from the above results: The response to pheromone may produce a relatively weak $\mathrm{Ca}^{2+}$ signal that is insufficient to induce low-sensitivity genes. In support of this hypothesis, overexpression of Tcnlp from a high dosage plasmid restored the calcineurin-dependent induction of PMC1-lacZ in response to pheromone treatment to $\sim 30 \%$ of maximal levels (Fig. 7A). Additionally, pheromone treatment caused a marked calcineurin-dependent induction of the high sensitivity GAL1-lacZ reporter driven by the Gal4(DB)::Tcn1(N) hybrid transcription factor amounting to $\sim 50 \%$ of the maximal induction observed upon treatment with both pheromone and high $\mathrm{Ca}^{2+}$ (Fig. 7B). These results suggest pheromone treatment generates a relatively weak $\mathrm{Ca}^{2+}$ signal that is ordinarily insufficient to induce low sensitivity genes such as PMC1 and possibly TCN 1.

Overexpression of Tcnlp failed to restore calcineurindependent induction to PMC1-lacZ by high salt treatment and failed to overcome the inhi bitory effect of high salt on PMC1-lacZ induction by high $\mathrm{Ca}^{2+}$ treatment (Fig. 7A). In contrast, treatment with high salt caused 
$\sim 25 \%$ maximal calcineurin-dependent induction of GAL1-lacZ in cells expressing the Gal4(DB)::Tcn1(N) hybrid transcription factor and had only a slight inhibitory effect on induction by high $\mathrm{Ca}^{2+}$ (Fig. 7B). The simplest hypothesis consistent with these results is that the re sponse to high salt includes both the promoter-specific
A

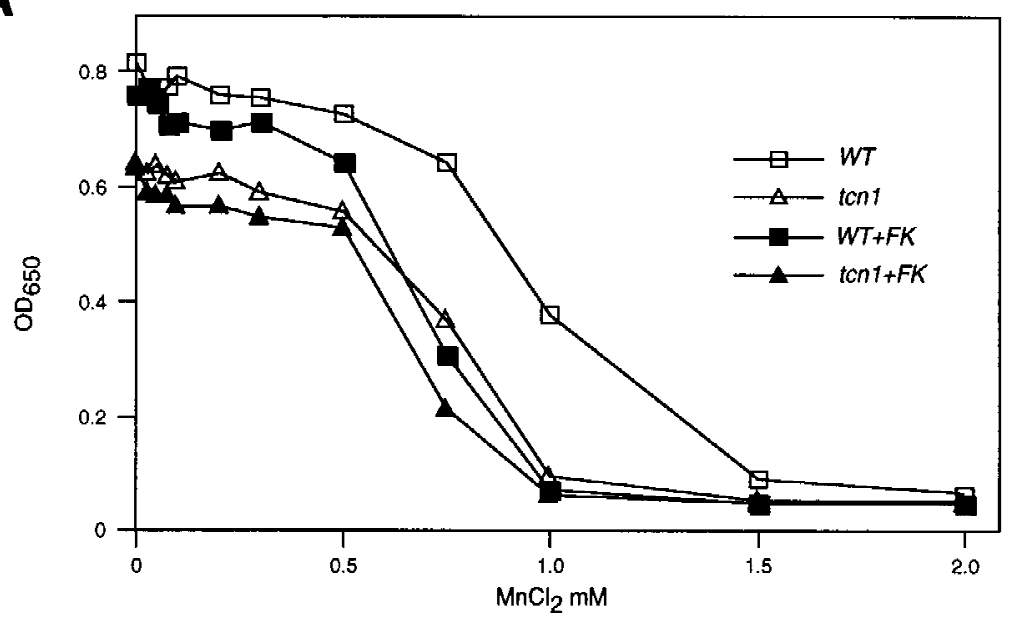

B

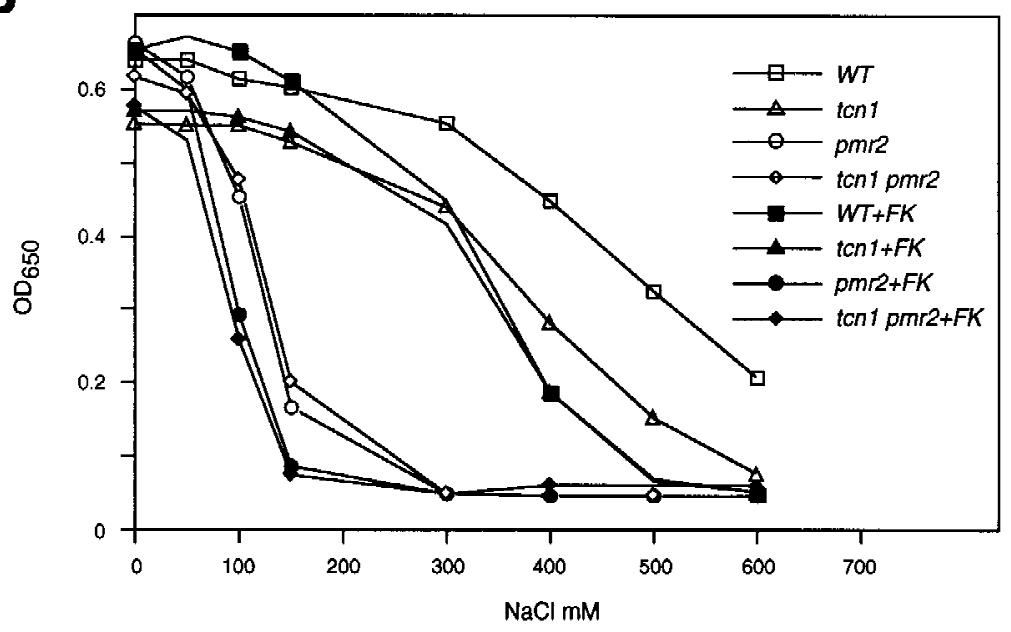

C

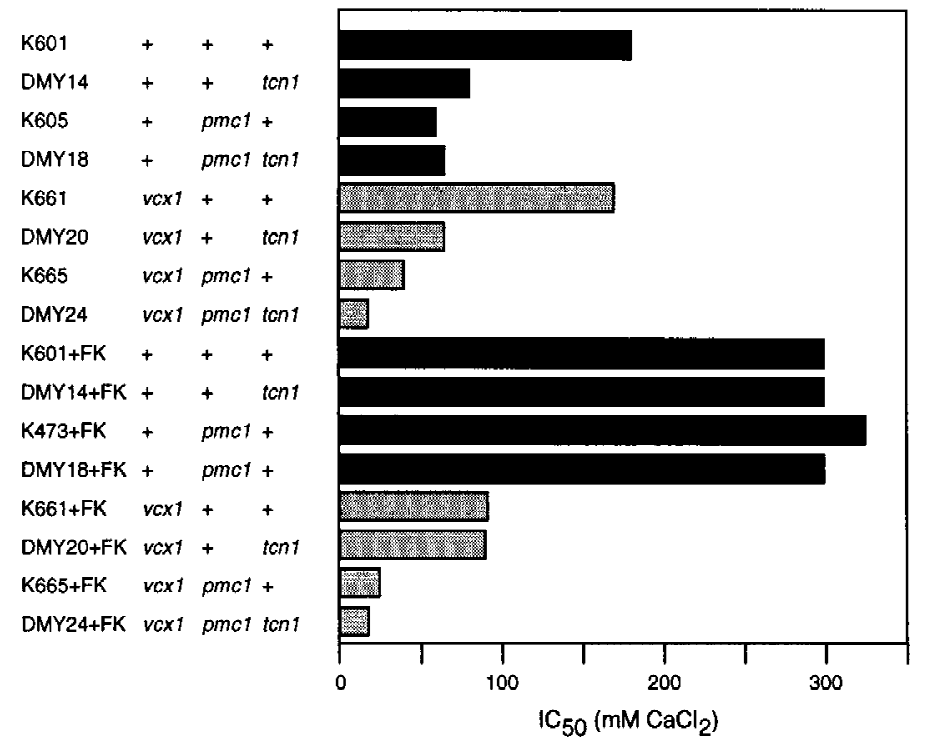

Figure 4. $\mathrm{Mn}^{2+}, \mathrm{Na}^{+}$, and $\mathrm{Ca}^{2+}$ tolerance assays of various yeast mutants showing roles of Tcnlp. All strains were grown to saturation in YPD medium at $30^{\circ} \mathrm{C}$ and diluted 1000 -fold into fresh media containing a range of $\mathrm{MnCl}_{2}$, $\mathrm{N} \mathrm{aCl}$, or $\mathrm{CaCl}_{2}$ concentrations (with and without $0.2 \mu \mathrm{g} / \mathrm{ml}$ of FK506) and incubated for 1 day at $30^{\circ} \mathrm{C}$ in flat-bottom 96 -well dishes $(0.2 \mathrm{ml} /$ well). Optical density at $650 \mathrm{~nm}$ was measured for each resuspended culture and plotted directly $(A, B)$ or plotted and used to determine the $50 \%$ inhibitory concentration or $\mathrm{IC}_{50}(\mathrm{C})$ as described in Materials and M ethods. 


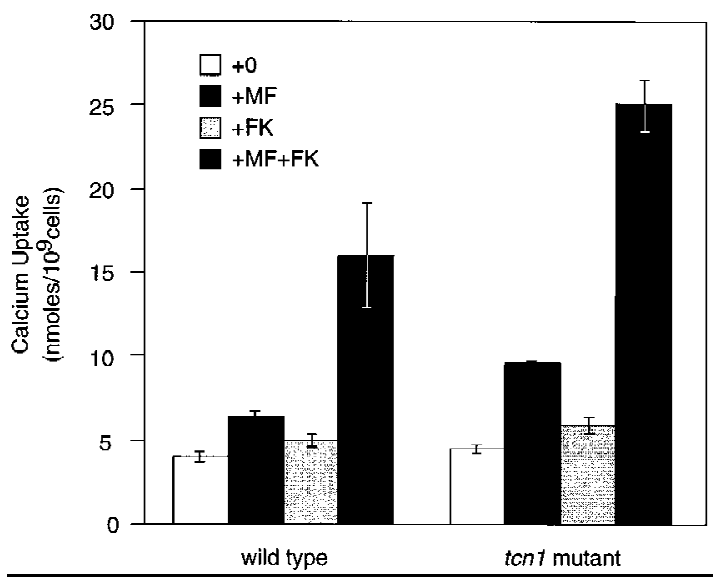

Figure 5. Tcnlp is not required for calcineurin-dependent inhibition of $\mathrm{Ca}^{2+}$ uptake stimulated by pheromone. Log-phase cells were incubated for $4 \mathrm{hr}$ at $30^{\circ} \mathrm{C}$ in YPD medium supplemented with ${ }^{45} \mathrm{Ca}^{2+}$ tracer in the presence or absence of synthetic pheromone [10 $\mu \mathrm{m}$ of $\alpha$-mating factor (MF)] and FK506 $(1.0 \mu \mathrm{g} / \mathrm{ml})$. Total cell-associated $\mathrm{Ca}^{2+}$ was determined as described in $M$ aterials and $M$ ethods, and the average of three independent experiments are shown ( \pm S.D.). A large stimulatory effect of FK506 was observed for both the wild-type (strain W303-1A) and ten1 null mutant (strain DMY14).

blockers of gene expression and the production of relatively weak $\mathrm{Ca}^{2+}$ signals that are sensed by calcineurin and the amino-terminal domain of Tcnlp. Based on all these results, we conclude that differential expression of Tcnlp-dependent genes can be accomplished through mechanisms that distinguish both the strength of $\mathrm{Ca}^{2+}$ signals and inputs from other signaling pathways.

\section{Discussion}

The results reported here and elsewhere (Stathopoulos and Cyert 1997) propose that Tcnlp/Crzlp functions as an important part of a calcineurin-dependent transcription factor in yeast. Tcnlp contains within its aminoterminal region a domain that interacts functional ly, and perhaps physically, with activated calcineurin. Genetic analyses of tcnl null mutants suggest that Tcnlp functions downstream of calcineurin in the calcium signaling pathway on a branch leading to the expression of specific genes. Tcnlp contains three zinc finger motifs in its carboxy-terminal region resembling the DNA-binding domains of numerous transcription regulators and has been shown in vitro to bind a 24-bp el ement present in the promoter of at least one target gene (Stathopoul os and Cyert 1997). The simplest molecular mechanism consistent with these results would be that calcineurin di rectly dephosphorylates $\mathrm{T} \mathrm{cn} 1 \mathrm{p}$ in response to $\mathrm{Ca}^{2+}$ signals and thereby stimulates either nuclear localization or transcriptional activation activity. The available data, however, do not rule out the involvement of unknown intermediary factors or additional steps in the mechanism. Regardless of the molecular mechanism, the analysis of ten 1 null mutants and its gain-of-function variants clarify the roles of specific factors in the calcium signaling pathway during the responses to high $\mathrm{Ca}^{2+}$, high salt, and mating pheromones.

\section{Regulation of calcium transporters}

The identification and characterization of Tcnlp confirms our previous model of $\mathrm{Ca}^{2+}$ homeostasis in yeast (Cunningham and Fink 1996) and extends our under-

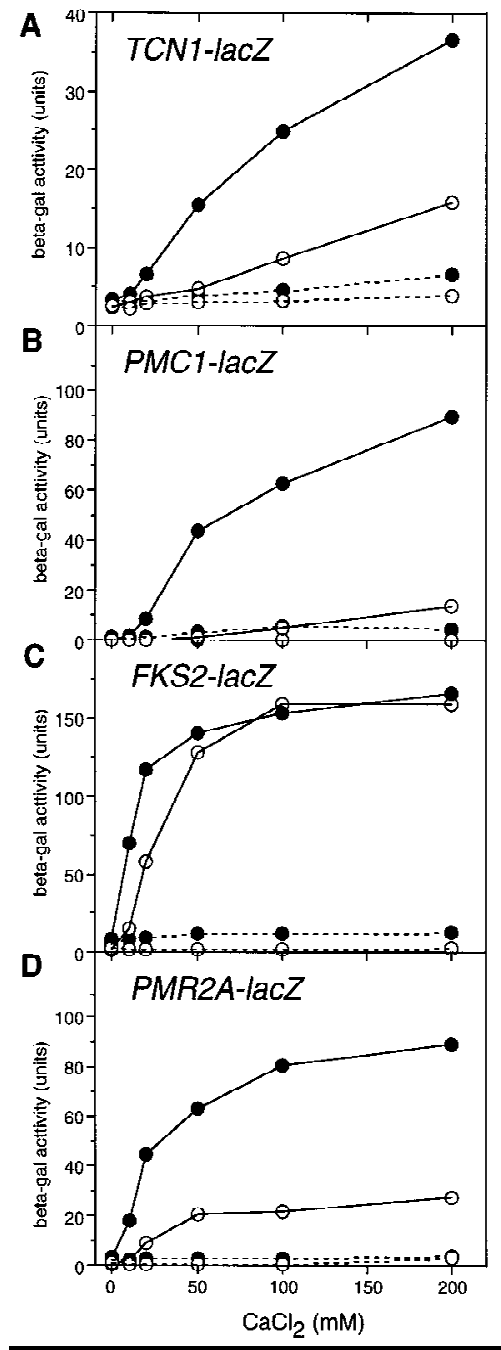

Figure 6. Cal cineurin-dependent induction of TCN 1-lacZ and other reporter genes is enhanced by overexpression of $T c n 1 p$. Wild-type yeast (strain W303-1A) carrying the indicated reporter genes (plasmids pDM 7, pKC190, pDM5, and pKC201, respectively) were transformed with either a control plasmid (YEp13, O) or a similar high dosage plasmid containing TCN 1 $(\mathrm{pLE66}, \mathbf{)})$ and grown to log phase in SC - ura -leu medium to maintain plasmid selection. After incubation for $4 \mathrm{hr}$ at $30^{\circ} \mathrm{C}$ in YPD (pH 5.5) medium supplemented with $\mathrm{CaCl}_{2}$ as indicated and either with FK506 $(0.4 \mu \mathrm{g} / \mathrm{ml}$, broken lines) or without FK506 (solid lines), cells were collected and assayed for $\beta$-gal actosidase accumulation. 


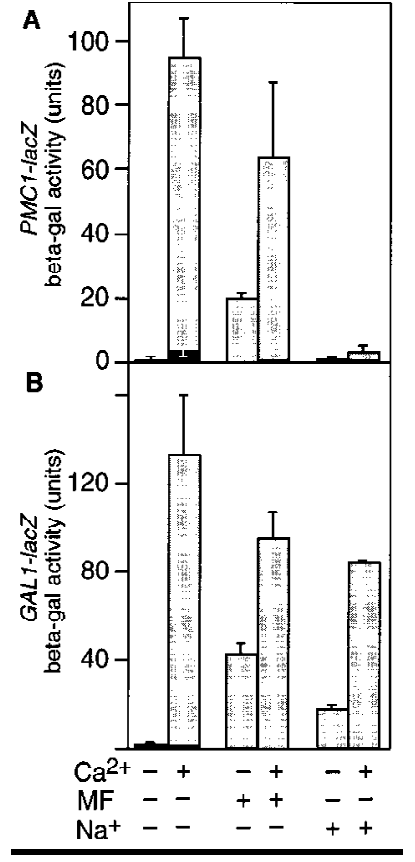

Figure 7. Differential expression of Tcnlp-dependent genes in response to strength of $\mathrm{Ca}^{2+}$ signals and other regulatory inputs. (A) Wild-type strain W303-1A was transformed with both plasmid pKC190 carrying PMC1-lacZ and plasmid pLE66 to increase dosage of $T \mathrm{cn} 1 \mathrm{p}$, grown, and assayed for $\beta$-galactosidase activity as described in Fig. 1. (B) The MATa gal 4 gal 80 strain Y 190 containing a GAL1-lacZ reporter gene was transformed with plasmid pDM 15 expressing the Gal 4(DB)::T cn1(N) hybrid factor and then grown and assayed as above. The results suggest pheromone produces a weak $\mathrm{Ca}^{2+}$ signal that partially induces a high sensitivity reporter $(B)$ but fails to induce a low sensitivity reporter unless Tcnlp is overexpressed (cf. A with Fig. 1A). High salt treatment induces the high sensitivity reporter and pre vents induction of PMC1-lacZ by high $\mathrm{Ca}^{2+}$ treatment despite overexpression of Tcnlp.

standing of the feedback mechanisms controlling $\mathrm{Ca}^{2+}$ transporters. Briefly, we propose that as extracellular $\mathrm{Ca}^{2+}$ concentrations are increased from $0.1 \mathrm{~mm}$ to $>100$ $\mathrm{mm}$ the higher rates of $\mathrm{Ca}^{2+}$ influx elevate cytosolic $\mathrm{Ca}^{2+}$ to levels which activate calcineurin and Tcnlp, leading first to induction of PMR1 and eventually to induction of TCN1 and PMC1. Expression of the vacuolar $\mathrm{Ca}^{2+}$ ATPase Pmclp correlates with $\mathrm{Ca}^{2+}$ tolerance and is consistent with a primary role of the vacuole in the sequestration of excess $\mathrm{Ca}^{2+}$ and precipitation with polyphosphate (Dunn et al . 1994). Previous work showed deletion of both PMC1 and PMR 1 is lethal due to accumulation of toxic levels of $\mathrm{Ca}^{2+}$ in the cytoplasm (Cunningham and Fink 1994). Basal expression of either $\mathrm{Ca}^{2+}$ ATPase is sufficient for viability because ton $1 \mathrm{mu}$ tants, pmc1 ton 1 double mutants, and pmr1 ton 1 double mutants are all viable though highly sensitive to added $\mathrm{Ca}^{2+}$ (Fig. 4; data not shown). In high $\mathrm{Ca}^{2+}$ conditions, the essential function of Tcnlp appears to be the induction of PMCl gene expression.
The analysis of ton1 mutants al so clarifies the role of calcineurin in $\mathrm{Mn}^{2+}$ tolerance. Pmrlp contributes strongly to $\mathrm{Mn}^{2+}$ tolerance but contributes much less than Pmclp to $\mathrm{Ca}^{2+}$ tolerance (Cunningham and Fink 1994). Strains lacking calcineurin or T cn1p function fail to induce PM R1-lacZ (T able 2 ) and are correspondingly less tolerant of added $\mathrm{Mn}^{2+}$ (Fig. 4A). This correlation suggests that Pmrlp levels directly determine $\mathrm{Mn}^{2+}$ tolerance just as Pmclp levels directly determine $\mathrm{Ca}^{2+}$ tolerance levels. An alternative hypothesis proposed the role of cal cineurin in $\mathrm{Mn}^{2+}$ tolerance was to limit $\mathrm{Mn}^{2+}$ influx by an unknown process (Farcasanu et al. 1995). However, a significant role for calcineurin in $\mathrm{Mn}^{2+}$ tolerance can only be detected when both Tcnlp and Pmrlp are functioning (Fig. 4A; Cunningham and Fink 1994). All of these results are consistent with a model in which calcineurin and Tcnlp induce expression of Pmrlp, which increases both $\mathrm{Mn}^{2+}$ sequestration in late compartments of the secretory pathway and $\mathrm{Mn}^{2+}$ export from the cell. Several other observations support this model. Mutants lacking PMR1 also display numerous secretory defects that can be attributed to insufficient $\mathrm{Ca}^{2+}$ and $\mathrm{Mn}^{2+}$ accumulation in compartments of the secretory pathway (Rudol ph et al. 1989; Antebi and Fink 1992). Sufficient $\mathrm{Ca}^{2+}$ and/or $\mathrm{Mn}^{2+}$ is required for viability (Loukin and Kung 1995), and pmr1 mutants require much higher levels of these metals than wild type in spite of their increased uptake and sensitivity (Lapinskas et al. 1995). These findings are consistent with a model in which Pmrlp supplies compartments of the secretory pathway with $\mathrm{Ca}^{2+}$ and $\mathrm{Mn}^{2+}$ during standard conditions and promotes $\mathrm{Mn}^{2+}$ tol erance by sequestration and eventual export. Further analysis of tcn 1 mutants and $\mathrm{Mn}^{2+}$ transport by Pmrlp and other factors (Supek et al. 1996) may resolve this issue.

Because calcineurin-dependent inhibition of the vacuol ar $\mathrm{H}^{+} / \mathrm{Ca}^{2+}$ exchanger Vcxlp is independent of Tcnlp (Fig. 4C), the analysis of tcn 1 mutants shed little light on the mechanisms regulating Vcxlp or on the physiological significance of this regulation. Previous work suggested that calcineurin may inhibit Vcxip post-translationally, although other explanations were not ruled out (Cunningham and Fink 1996). Why yeast cells inhibit Vcxlp when this enzyme can greatly increase $\mathrm{Ca}^{2+}$ tolerance also remains unclear. However, analysis of constitutive mutant forms of Vcxlp that resist inhibition by cal cineurin reveal ed inappropriate $\mathrm{H}^{+} / \mathrm{Ca}^{2+}$ exchange decreases the availability of cytosolic $\mathrm{Ca}^{2+}$ for cal cium signaling (Cunningham and Fink 1996) and potentially for transport by Pmrlp into the secretory pathway.

\section{Calcium signaling in response to salt stress}

Evidence reported here and in previous studies all suggest that the response to high salt includes activation of the calcium signaling pathway, although no change in $\mathrm{Ca}^{2+}$ influx or accumulation in the cytosol has been reported. We observed submaximal induction of the Gal 1lacZ reporter by Gal4(DB)::T cn1(N) after treatment with high salt (Fig. 7), and in tcn1 mutants we observed de- 
creases in $\mathrm{Na}^{+}$tolerance and PMR2A expression. These results suggest that high salt may generate a weak $\mathrm{Ca}^{2+}$ signal that mildly activates the calcium signaling pathway. In addition, calcineurin contributes to $\mathrm{Na}^{+}$tolerance independently of T cn1p and the Pmr2p ion pumps (Fig. 4B; Danielsson et al. 1996; Mendoza et al. 1996). Finally, $\mathrm{Ca}^{2+} /$ calmodulin promotes $\mathrm{Na}^{+}$tolerance by binding and activating Pmr2p ion pumps (Wiel and et al . 1995). Together, these findings demonstrate multi ple interactions between the calcium signaling pathway and $\mathrm{Na}^{+}$tolerance factors. Another response to high salt appears to be negative regulation of genes such as PMC1 and FKS2 (Figs. 1 and 7). High salt may activate specific repressors or inhibit specific coactivators of transcription such as the MSN5/STE21 gene product, which is important together with Tcnlp for calcineurin-dependent induction of FKS2 and PMC1 (P.M. Alepuz, D.P. $M$ atheos, K.W. Cunningham, and F. Estruch, in prep.).

\section{Calcium signaling during the pheromone response}

There is abundant evidence that $\mathrm{Ca}^{2+}$ signals are generated in yeast after treatment with high doses of mating pheromones (Ohsumi and A nraku 1985) and that the calcium signaling pathway becomes activated and induces genes such as FKS2 (Mazur et al. 1995). Here we show that induction of FKS2 in response to pheromone treatment also requires Tcnlp. The pattern of FKS2 expression contrasts with other Tcnlp-dependent genes and suggests that the pheromone response generates a relatively weak $\mathrm{Ca}^{2+}$ signal that is insufficient for induction of low-sensitivity genes such as PMC1, which required overexpression of Tcnlp before a significant response to pheromone could be observed (Fig. 7). In spite of this clear role for Tcnlp in the response to pheromone, we detected no significant role for Tcnlp in several other calcineurin-responsive phenomena, including feedback inhibition of $\mathrm{Ca}^{2+}$ uptake (Fig. 5), changes in cell morphology, or promoting cell survival during pheromone stimulation (not shown). Survival in pheromone was shown previously to depend on $\mathrm{Ca}^{2+}$ influx and the functions of calmodulin, cal cineurin, and calmodulin-dependent protein kinases (lida et al. 1990, 1994; Moser et al. 1996; Withee et al. 1997). The targets of the calcium signaling pathway involved in cell survival therefore remain to be identified.

\section{Comparison of $\mathrm{Ten} 1 \mathrm{p}$ regulation} with vertebrate systems

The cal cineurin-dependent transcriptional activation domain of Tcnlp shows no significant sequence similarity to other proteins in current databases, so extrapolations to specific vertebrate mechanisms are not yet possible. Several parallels are noteworthy, nevertheless. Using the zinc finger domain of Tcnlp to search protein databases, the most similar vertebrate proteins are members of the EGR family of transcription factors. Zif268/EGR-1 is markedly induced by calcium signaling through the serum response factor SRF in many cell types (Cole et al.
1989; Ginty 1997), and induction of EGR-2 in B cells al so depends on cal cineurin function (Gottschalk et al. 1994). In these cases, the molecular mechanisms controlling EGR expression are not precisely known. We show evidence that Tcn $1 p$ may regulate its own expression by a positive feedback mechanism requiring calcineurin and that this autoregulation may affect expression of target genes such as PMC1. Remarkably, expression of vertebrate PMCA genes encoding the pl asma membrane $\mathrm{Ca}^{2+}$ ATPases homologous to Pmclp also appears to be regulated in response to $\mathrm{Ca}^{2+}$ signals and cal cineurin activation in granule cells of the developing rat cerebellum (Carafoli et al. 1996).

An emerging question in understanding signal transduction networks is how cells utilize common signaling modules to generate distinct outputs depending on the type or source of input signal. In neurons, for example, $\mathrm{Ca}^{2+}$ signals generated by either activation of the N M DA receptor or activation of the L-type $\mathrm{Ca}^{2+}$ channel caused phosphorylation of the critical serine-133 in the CREB transcription factor but only the signal derived from the L-type channel could induce the c-fos gene (Bading et al. 1993). Differences in the spatial or temporal character of these $\mathrm{Ca}^{2+}$ signals have been proposed to accomplish this type of differential gene expression (Dolmetsch et al. 1997; Ginty 1997) although differences in $\mathrm{Ca}^{2+}$ signal strength or additional regulatory mechanisms anal ogous to those reported here may also be involved. Although the spati otemporal characteristics of the $\mathrm{Ca}^{2+}$ signals in yeast caused by pheromone, high salt, and high $\mathrm{Ca}^{2+}$ are presently unknown, our results indicate that different promoters are sensitive to variations in the strength of $\mathrm{Ca}^{2+}$ signals and inputs from other types of signaling pathways. More work is needed to understand this phenomenon and to accurately compare the yeast mechanism with mammalian systems.

\section{Materials and methods}

Culture media and isolation/construction of ten 1 mutants

Synthetic complete (SC) and complex (YPD) media were prepared and supplemented with $2 \%$ glucose as described previously (Sherman et al. 1986) using reagents from Difco and Sigma Chemical Co. Where indicated, YPD medium was buffered to $\mathrm{pH} 5.5$ by addition of $5 \mathrm{~mm}$ succinic acid and supplemented with various salt such as $\mathrm{CaCl}_{2}, \mathrm{MnCl}_{2}, \mathrm{NaCl}$, or $\mathrm{G} 418$ sulfate. FK506 was generously provided by Fujisawa Corp. (Tokyo, Japan). The synthetic pheromone $\alpha$-mating factor was obtained from Star Biochemicals.

All yeast strains listed in T able 2 were derived from W303-1A (Wallis et al. 1989) using standard methods of transformation and/or crossing (Sherman et al. 1986), and all strains except Y190 harbored the following genetic markers: MATa ade2-1 can1-100 his3-1 leu2-3,112 trp1-1 ura3-1. The ton1::kanMX3 null mutation in which the chromosomal TCN1 gene was deleted and replaced was introduced into W303-1A by one-step gene replacement (Rothstein 1991) using a fragment of plasmid pKC287 generated by digestion with Bgl II plus Xbal. The resulting tcn1 null mutant (strain DMY 14) was selected in YPD agar medium supplemented with $0.2 \mathrm{mg} / \mathrm{ml}$ of G 418 sul fate (GIBCO $B R L$ ) and verified by PCR analysis of genomic DNA. Additional 
strains containing tcn1::kanMX3 were constructed by crosses between DMY 14 and previously described derivatives of W3031A (Cunningham and Fink 1996). Strains DMY 62 and DMY 63 were constructed by transformation of strains K 473 and K482, respectively, with A pal-digested plasmid pKC217, which integrates a PMC 1-lacZ reporter gene at the ura3-1 locus. $\beta$-Galactosi dase accumulation in strains DM Y 62 and DMY 63 was very low during growth in YPD (pH 5.5) medium and very high after growth in YPD (pH 5.5) medium supplemented with $\mathrm{CaCl}_{2}$ as detected using the chromogenic substrates O-nitrophenyl- $\beta$ D-galactopyranoside (ON PG) as described (Guarente 1983) or 5-bromo-4-chloro-3-indolyl- $\beta$-D-gal actopyranoside (X-gal, see below).

To identify mutants unable to induce PMC1-lacZ, strains DMY 62 and DM Y 63 were mutagenized to $~ 30 \%$ viability using EMS, spread onto 40 plates of SC minus uracil agar medium at a density of $\sim 1000$ colonies/plate, and grown at $30^{\circ} \mathrm{C}$ for 3 days. Colonies were then replica-plated onto paper filters (Whatman $\mathrm{No}$. 3) placed on YPD (pH 5.5) agar plates supplemented with 0.3 $\mathrm{mm}$ adenine and $75 \mathrm{~mm} \mathrm{CaCl}_{2}$, incubated for 1 day at $30^{\circ} \mathrm{C}$, and assayed for $\beta$-galactosidase accumulation as follows. Filters were first soaked with $25 \mathrm{~mm}$ EGTA (pH 7.5) for $\sim 20 \mathrm{~min}$ at room temperature, plunged into liquid nitrogen for $\sim 1 \mathrm{~min}$, and finally soaked $\sim 3 \mathrm{hr}$ at room temperature with staining solution containing $0.3 \mathrm{mg} / \mathrm{ml}$ of X-gal dissolved in modified Z buffer [100 mM Na phosphate (pH 7.0), $10 \mathrm{~mm} \mathrm{KCl,} 10 \mathrm{~mm} \mathrm{MgSO}$, $0.1 \%$ SDS, $0.27 \% \beta$-mercaptoethanol]. Most colonies stained dark blue after this protocol. All white or light blue colonies were collected, purified, retested, and then subjected to complementation testing where each DMY 62 isolate was mated with each DMY63 isolate in all possible combinations and the resulting diploids were selected on SC - Leu-Trp agar medium and tested for $\beta$-gal actosi dase accumulation after cal cium treatment as before. All recessive mutations were placed into one of three complementation groups-cnb1, msn5, and tcn1-which were identified by cloning of the functional loci by complementation and/or allelism tests using targeted disruption mutants.

\section{Cloning of TCN 1 and recombinant DNA}

All recombinant DNA techniques were performed using standard techniques (Sambrook et al. 1989) with reagents supplied by Stratagene and N ew England Biolabs. To identify the TCN 1 gene, a tcn 1 mutant isolated in the screen was transformed with a low-copy genomic DN A plasmid library (kind gift of D. Levin, Johns Hopkins U niversity, Baltimore, MD) based on the pRS313 shuttle vector (Sikorski and Hieter 1989), plated on SC - His agar medium, replica plated to filters placed on YPD (pH 5.5) agar medium containing $75 \mathrm{~mm} \mathrm{CaCl}$, and stained with X-gal as described above to identify rare blue clones that regained ability to express PMC1-lacZ. Out of $\sim 10,000$ independent transformants, 2 were found to yield plasmids that complemented the tcn 1 defect. Restriction mapping and partial sequencing of the insert DNA from both plasmids (pDM 1 and pDM 2) demonstrated that the two plasmids contain distinct but overlapping inserts spanning two previously uncharacterized open reading frames from chromosome XIV termed YNL026W and YNL027w. Deletion of YNL026w by digestion of pDM 1 with Spel plus Xbal, followed by religation, resulted in plasmid pDM 3, which retained the ability to complement tcn1 mutations. Prior to the rel ease of the complete yeast genomic DNA sequence, $A$. Duesterhoeft and P. Phillippsen generously provided the sequence of the TCN1 locus and plasmid p678::IacZkanMX3, which was used to construct the tcn 1::kanMX3 disruption plasmid pKC287 by digesting with Spel plus BsrGI to remove all lacZ sequences, generating blunt ends, and ligating (Philippsen et al. 1997). Null mutants obtained by gene replacement using tcn $1:$ kanM X3 DN A failed to complement each of the tcn 1 alleles isolated in the genetic screen, showing that the mutations in this group all resided within the TCN1/YNL027w gene.

Plasmids containing various reporter genes were constructed as follows. An integrating plasmid containing the PMC1-lacZ reporter gene (pKC217) was derived from pKC 190 (Cunningham and Fink 1996) after digestion with Spel and religation to remove the $2 \mu$ origin of replication. The FKS2-lacZ reporter plasmid (pDM 5) containing the DN A segment from position -968 to +6 relative to the initiation codon of FKS2 fused in-frame to lacZ coding sequences was constructed by PCR amplification with oligonucleotides FKS2A (GGAGTCGACAGGGCTACTCAATCG) and FKS2B (GCCTCTAGAGGACATACCTATGACAG) followed by digestion with Sall plus Xbal and cloning first into polylinker sites of YEp356R (Myers et al. 1986) and then subcloning into pLG $\Delta 178$ (Guarente and M ason 1983) after first digesting both plasmids with Xhol plus BamHI. A TCN1lacZ reporter plasmid (pDM 7) was constructed by subcloning the DNA segment from -1485 to +42 relative to the TCN 1 initiation codon from pDM 3 (liberated with Sall plus Spel) first into YEp356R (digested with Sall plus Xbal) and then subcloning the Sall plus BamHI fragment into $\mathrm{pLG} \Delta \mathbf{1 7 8}$ digested with Xhol plus BamHI.

All plasmids expressing Gal4 hybrid proteins were constructed from plasmids PPC97 and pPC86 (Chevray and $\mathrm{N}$ athans 1992) as follows. The amino-terminal region of Tcnlp corresponding to nucleotides +33 to +1381 was amplified using oligonucleotides DB1 (GCCGCCAATATGGCGTCGACCATGACTAGTAGTAAT) and DB2 (GCCGCCATTGTCATCCTAGGCCCGATTATTGTCATT), purified on agarose gels, digested with Sall plus Avrll, and cloned into pPC 97 digested with Sall plus Spel to yield pDM 15 containing Gal4(DB)::Tcn1(N). Plasmid pDM 16 expressing $\operatorname{Tn} 1(C):: G a l 4(A D)$ hybrid proteins was constructed by ligating into Sall plus Spel-digested pPC 86 the Sall plus A vrll-digested PCR product obtained using primers TA1 (GCCGCCAATCGGGAGTCGACTGACAATGATAGCAAA) and TA2 (GCCGCCTTAACTCCTAGGCTCTTGTCCCGATTTCTC), corresponding to nucleotides +1389 to +2033 of TCN1. Plasmids pKC116 and pKC117 containing Gal4(DB):: Cnal $\Delta C$ and Gal4(DB)::Cnal hybrids, respectively, were constructed by subcloning the Xhol plus BamHI fragments of pKC73 and pKC74 (Cunningham and Fink 1996) into pPC97 digested with Sall plus BamHI. Plasmid pTJK27 containing Tcn1(N)::Gal4(AD) was constructed by subcloning a Sall plus Sstl fragment from pDM 15 into pPC 86 digested with Sall plus Sstl.

\section{$\beta$-Galactosidase assays}

Strains were grown overnight in SC media lacking uracil to mid-log phase, harvested, and grown for an additional $4 \mathrm{hr}$ in either YPD or YPD (pH 5.5) supplemented with $\mathrm{CaCl}_{2}, \mathrm{NaCl}$, $\alpha$-mating factor, and/or FK506 as indicated in the text. $\beta$-Galactosidase activity was assayed at room temperature using chloroform/SDS permeabilized cells as described previously (Guarente 1983).

\section{Ion tolerance assay}

Ion tolerance assays were performed as described previously (Cunningham and Fink 1996). For $\mathrm{CaCl}_{2}$, yeast strains were grown in YPD (pH 5.5), whereas $\mathrm{MnCl}_{2}$ and $\mathrm{NaCl}$ assays used YPD media. Cell density was measured at an $\mathrm{OD}_{650}$ with a M olecular Devices microplate reader. The concentration of cat- 
ion resulting in a $50 \%$ decrease in cell growth relative to unsupplemented cultures $\left(\mathrm{IC}_{50}\right)$ was interpolated from linear plots of the ion tolerance data.

\section{$\mathrm{Ca}^{2+}$ uptake assays}

Yeast cultures were grown to mid-log phase at $30^{\circ} \mathrm{C}$ in $Y P D$ media, harvested, and resuspended to an $\mathrm{OD}_{600}$ of $0.25 \mathrm{in} 0.2 \mathrm{ml}$ of YPD and supplemented with $\sim 10 \mathrm{mCi} / \mathrm{ml}$ of ${ }^{45} \mathrm{Ca}^{2+}$ (Amersham Life Science). After incubation for $4 \mathrm{hr}$ at $30^{\circ} \mathrm{C}$ with occasional mixing, $0.18 \mathrm{ml}$ of culture was filtered through Whatman GFF filters and washed three times with buffer $(5 \mathrm{mM} \mathrm{Na}$ HEPES, $10 \mathrm{mM} \mathrm{CaCl}_{2}$ at $\mathrm{pH}$ 6.5). Filters were dried and radioactivity quantitated using a scintillation counter. ${ }^{45} \mathrm{Ca}^{2+}$ accumulation per $10^{9}$ cells was cal culated using the measured radioactivity retained on filters, the specific activity, and the cell density as determined by culture density using $\mathrm{OD}_{600}$.

\section{Acknowledgments}

We are indebted to Andreas Duesterhoeft and Peter Philippsen for generously providing DN A sequences prior to publication as well as yeast strains and plasmids. We are very grateful to Paula Alepuz, Trisha Davis, Cameron Douglas, Francisco Estruch, and David Levin for providing reagents and advice and to Fujisawa Corp. for gifts of FK506. This work was supported jointly by the Searle Scholars Program/The Chicago Community Trust, the Basil O'Connor Starter Scholar Research Award (FY96-1131) from the March of Dimes Birth Defects Foundation, and a Research Grant from $\mathrm{N}$ ational Institutes of Health (GM 53082).

The publication costs of this article were defrayed in part by payment of page charges. This article must therefore be hereby marked "advertisement" in accordance with 18 USC section 1734 solely to indicate this fact.

\section{References}

Akada, R., L. Kallal, D.I. Johnson, and J. Kurjan. 1996. Genetic relationships between the $G$ protein $\beta-\gamma$ complex, Ste5p, Ste20p, and Cdc42p: Investigation of effector roles in the yeast pheromone response pathway. Genetics 143: 103-117.

Alepuz, P.M., K.W. Cunningham, and F. Estruch. 1997. Glucose repression affects ion homeostasis in yeast through the regulation of the stress activated ENA1 gene. Mol. Microbio. 26: 91-98.

Antebi, A. and G.R. Fink. 1992. The yeast Ca ${ }^{2+}$-ATPase homologue, PMR1, is required for normal Golgi function and localizes in a novel Golgi-like distribution. Mol. Biol. Cell 3: 633-654.

Bading, H., D.D. Ginty, and M.E. Greenberg. 1993. Regulation of gene expression in hippocampal neurons by distinct calcium signaling pathways. Science 260: 181-186.

Carafoli, E., E. Garcia-M artin, and D. Guerini . 1996. The plasma membrane calcium pump: recent developments and future perspectives. Experientia 52: 1091-1100.

Chevray, P.M. and D. N athans. 1992. Protein interaction cloning in yeast: Identification of mammalian proteins that react with the leucine zipper of Jun. Proc. Natl. Acad. Sci. 89: 5789-5793.

Cole, A.J., D.W. Saffen, J.M. Baraban, and P.F. Worley. 1989. Rapid increase of an immediate early gene messenger RN A in hippocampal neurons by synaptic NMDA receptor activation. Nature 340: 474-476.

Collier, S.J. 1990. Immunosuppressive drugs. Curr. Opin. Im- munol. 2: 854-858.

Cunningham, K.W. and G.R. Fink. 1994. Calcineurin-dependent growth control in Saccharomyces cerevisiae mutants lacking PMC1, a homolog of plasma membrane $\mathrm{Ca}^{2+}$ ATPases. J. Cell Biol. 124: 351-363.

- - 1996. Calcineurin inhibits VCX1-dependent $\mathrm{H}^{+} / \mathrm{Ca}^{2+}$ exchange and induces $\mathrm{Ca}^{2+} \mathrm{ATP}$ Tases in yeast. Mol. Cell. Biol. 16: 2226-2237.

Cyert, M.S. and J. Thorner. 1992. Regulatory subunit (CNB1 gene product) of yeast $\mathrm{Ca}^{2+} /$ cal modulin-dependent phosphoprotein phosphatases is required for adaptation to pheromone. Mol. Cell. Biol. 12: 3460-3469.

Cyert, M.S., R. Kunisawa, D. Kaim, and J. Thorner. 1991. Yeast has homologs (CNA1 and CNA2 gene products) of mammalian calcineurin, a calmodulin-regulated phosphoprotein phosphatase. Proc. Natl. Acad. Sci. 88: 7376-7380.

Danielsson, A., C. Larsson, K. Larsson, L. Gustafsson, and L. Adler. 1996. A genetic analysis of the role of calcineurin and calmodulin in $\mathrm{Ca}^{2+}$-dependent improvement of $\mathrm{NaCl}$ tolerance of Saccharomyces cerevisiae. Curr. Genet. 30: 476-484.

Davis, T.N., M.S. Urdea, F.R. Masiarz, and J. Thorner. 1986. Isolation of the yeast calmodulin gene: calmodulin is an essential protein. Cell 47: 423-431.

Dolmetsch, R.E., R.S. Lewis, C.C. Goodnow, and J.I. Healy. 1997. Differential activation of transcription factors induced by $\mathrm{Ca}^{2+}$ response amplitude and duration. Nature 386: 855858.

Dunn, T., K. Gable, and T. Beeler. 1994. Regulation of cellular $\mathrm{Ca}^{2+}$ by yeast vacuoles. J. Biol. Chem. 269: 7273-7278.

Eng, W.K., L. Faucette, M.M. M cLaughlin, R. Cafferkey, Y. Koltin, R.A. Morris, P.R. Young, R.K. Johnson, and G.P. Livi. 1994. The yeast FKS1 gene encodes a novel membrane protein, mutations in which confer FK506 and cyclosporin A hypersensitivity and calcineurin-dependent growth. Gene 151: 61-71.

Farcasanu, I.C., D. Hirata, E. Tsuchiya, F. Nishiyama, and T. Miyakawa. 1995. Protein phosphatase 2B of Saccharomyces cerevisiae is required for tolerance to manganese, in blocking the entry of ions into the cells. Eur. J. Biochem. 232: 712717.

Fields, S. and R. Sternglanz. 1994. The two-hybrid system: An assay for protein-protein interactions. Trends Genet. 10: 286-292.

Foor, F., S.A. Parent, N. Morin, A.M. Dahl, N. Ramadan, G. Chrebet, K.A. Bostian, and J.B. Nielsen. 1992. Calcineurin mediates inhibition by FK506 and cyclosporin of recovery from al pha-factor arrest in yeast. Nature 360: 682-684.

Garciadeblas, B., F. Rubio, F.J. Quintero, M.A. Banuelos, R. $\mathrm{H}$ aro, and A. Rodriguez-N avarro. 1993. Differential expression of two genes encoding isoforms of the ATPase involved in sodium efflux in Saccharomyces cerevisiae. Mol. \& Gen. Genet. 236: 363-368.

Garrett-Engele, P., B. Moilanen, and M.S. Cyert. 1995. Calcineurin, the $\mathrm{Ca}^{2+} / \mathrm{cal}$ modulin-dependent protein phosphatase, is essential in yeast mutants with cell integrity defects and in mutants that lack a functional vacuolar $\mathrm{H}^{+}$ATPase. Mol. Cell. Biol. 15: 4103-4114.

Geiser, J.R., D. van Tuinen, S.E. Brockerhoff, M.M. N eff, and T.N. Davis. 1991. Can calmodulin function without binding calcium? Cell 65: 949-959.

Ginty, D.D. 1997. Calcium regulation of gene expression: Isn't that spatial? Cell 18: 183-186.

Gottschalk, A.R., L.J. Joseph, and J. Quintans. 1994. Fc gamma RII cross-linking inhibits anti-lg-induced Egr-1 and Egr-2 expression in BCL1. J. Immunol. 152: 2115-2122.

Guarente, L. 1983. Y east promoters and lacZ fusions designed 
to study expression of cloned genes in yeast. Methods Enzymol. 101: 181-191.

Guarente, L. and T. M ason. 1983. Heme regulates transcription of the CYC1 gene of S. cerevisiae via an upstream activation site. Cell 32: 1279-1286.

Haro, R., B. Garciadeblas, and A. Rodriguez-N avarro. 1991. A novel P-type ATPase from yeast involved in sodium transport. FEBS Lett. 291: 189-191.

Harper, J.W., G.R. Adami, N. Wei, K. Keyomarsi, and S.J. Elledge. 1993. The p21 Cdk-interacting protein Cip1 is a potent inhibitor of $\mathrm{G} 1$ cyclin-dependent kinases. Cell 75: 805-816.

Hemenway, C.S., K. Dolinski, M.E. Cardenas, M.A. Hiller, E.W. Jones, and J. Heitman. 1995. vph6 mutants of Saccharomyces cerevisiae require calcineurin for growth and are defective in vacuolar $\mathrm{H}^{+} /$ATPase assembly. Genetics 141: 833844.

Hirata, D., S. Harada, H. N amba, and T. Miyakawa. 1995. Adaptation to high-salt stress in Saccharomyces cerevisiae is regulated by $\mathrm{Ca}^{2+} / \mathrm{calmodulin}$-dependent phosphoprotein phosphatase (calcineurin) and CAM P-dependent protein kinase. Mol. \& Gen. Genet. 249: 257-264.

lida, H., Y. Yagawa, and Y. Anraku. 1990. Essential role for induced $\mathrm{Ca}^{2+}$ influx followed by $\left[\mathrm{Ca}^{2+}\right]$ i rise in maintaining viability of yeast cells late in the mating pheromone re sponse pathway. A study of $\left[\mathrm{Ca}^{2+}\right] \mathrm{i}$ in single Saccharomyces cerevisiae cells with imaging of fura-2. J. Biol. Chem. 265: 13391-13399.

lida, H., H. N akamura, T. Ono, M.S. Okumura, and Y. Anraku. 1994. MID1, a novel Saccharomyces cerevisiae gene encoding a plasma membrane protein, is required for $\mathrm{Ca}^{2+}$ influx and mating. Mol. Cell. Biol. 14: 8259-8271.

Kuno, T., H. Tanaka, H. Mukai, C.D. Chang, K. Hiraga, T. Miyakawa, and C. Tanaka. 1991. cDN A cloning of a cal cineurin B homolog in Saccharomyces cerevisiae. Biochem. Biophys. Res. Commun. 180: 1159-1163.

Lapinskas, P.J., K.W. Cunningham, X.F. Liu, G.R. Fink, and V.C. Culotta. 1995. Mutations in PMR1 suppress oxidative damage in yeast lacking superoxide dismutase. Mol. Cell. Biol. 15: 1382-1388.

Lemaire, P., O. Revelant, R. Bravo, and P. Charnay. 1988. Two mouse genes encoding potential transcription factors with identical DN A-binding domains are activated by growth factors in cultured cells. Proc. Natl. Acad. Sci. 85: 4691-4695.

Liu, Y., S. Ishii, M. Tokai, H. Tsutsumi, O. Ohki, R. Akada, K. Tanaka, E. Tsuchiya, S. Fukui, and T. Miyakawa. 1991. The Saccharomyces cerevisiae genes (CMP1 and CMP2) encoding calmodulin-binding proteins homologous to the cataIytic subunit of mammalian protein phosphatase 2B. Mol. \& Gen. Genet. 227: 52-59.

Loukin, S. and C. Kung. 1995. M anganese effectively supports yeast cell-cycle progression in place of calcium. J. Cell Biol. 131: 1025-1037.

Mazur, P., N. M orin, W. Baginsky, M. El-Sherbeini, J.A. Clemas, J.B. Nielsen, and F. Foor. 1995. Differential expression and function of two homologous subunits of yeast 1,3-beta-Dglucan synthase. Mol. Cell. Biol. 15: 5671-5681.

Mendoza, I., F. Rubio, A. Rodriguez-N avarro, and J.M. Pardo. 1994. The protein phosphatase calcineurin is essential for $\mathrm{NaCl}$ tolerance of Saccharomyces cerevisiae. J. Biol. Chem. 269: 8792-8796.

Mendoza, I., F.J. Quintero, R.A. Bressan, P.M. Hasegawa, and J.M. Pardo. 1996. Activated calcineurin confers high tolerance to ion stress and alters the budding pattern and cell morphology of yeast cells. J. Biol. Chem. 271: 23061-23067.

Moser, M.J., J.R. Geiser, and T.N . Davis. 1996. $\mathrm{Ca}^{2+}$-calmodulin promotes survival of pheromone-induced growth arrest by activation of calcineurin and $\mathrm{Ca}^{2+}$-calmodulin-dependent protein kinase. Mol. Cell. Biol. 16: 4824-4831.

Myers, A.M., A. Tzagoloff, D.M. Kinney, and C.J. Lusty. 1986. Yeast shuttle and integrative vectors with multiple cloning sites suitable for construction of lacZ fusions. Gene 45: 299310.

N akajima-Shimada, J., H. Iida, F.I. T suji, and Y. Anraku. 1991. M onitoring of intracellular calcium in Saccharomyces cerevisiae with an apoaequorin cDN A expression system. Proc. Natl. Acad. Sci. 88: 6878-6882.

Nakamura, T., Y. Liu, D. Hirata, H. Namba, S. Harada, T. Hirokawa, and T. Miyakawa. 1993. Protein phosphatase type 2B (calcineurin)-mediated, FK506-sensitive regulation of intracellular ions in yeast is an important determinant for adaptation to high salt stress conditions. EMBO J. 12: 40634071.

Nakamura, T., T. Ohmoto, D. Hirata, E. Tsuchiya, and T. Miyakawa. 1996. Genetic evidence for the functional redundancy of the calcineurin- and M pk1-mediated pathways in the regulation of cellular events important for growth in Saccharomyces cerevisiae. Mol. \& Gen. Genet. 251: 211219.

N ass, R., K.W. Cunningham, and R. Rao. 1997. Intracellular sequestration of sodium by a novel $\mathrm{Na}^{+} / \mathrm{H}^{+}$exchanger in yeast is enhanced by mutations in the plasma membrane $\mathrm{H}^{+}$-ATPase. J. Biol. Chem. 272: 26145-26152.

Ohsumi, Y. and Y. Anraku. 1985. Specific induction of $\mathrm{Ca}^{2+}$ transport activity in MATa cells of Saccharomyces cerevisiae by a mating pheromone, $\alpha$ factor. J. Biol. Chem. 260: 10482-10486.

Ohya, Y., H. Kawasaki, K. Suzuki, J. Londesborough, and Y. Anraku. 1991. Two yeast genes encoding cal modulin-dependent protein kinases. Isolation, sequencing and bacterial expressions of CMK1 and CMK2. J. Biol. Chem. 266: 1278412794.

Parent, S.A., J.B. Nielsen, N. Morin, G. Chrebet, N. Ramadan, A.M. Dahl, J.-J. Hsu, K.A. Bostian, and F. Foor. 1993. Calcineurin-dependent growth of an FK506 and CsA hypersensitive mutant of Saccharomyces cerevisiae. J. Gen. Microbiol. 139: 2973-2984.

Pausch, M.H., D. Kaim, R. Kunisawa, A. Admon, and J. Thorner. 1991. Multiple $\mathrm{Ca}^{2+} /$ calmodulin-dependent protein kinase genes in a unicellular eukaryote. EMBO J. 10: 1511-1522.

Pavletich, N.P. and C.O. Pabo. 1991. Zinc finger-DNA recognition: Crystal structure of a Zif268-DNA complex at $2.1 \mathrm{~A}$. Science 252: 809-817.

Philippsen, P., K. Kleine, R. Pohlmann, A. Dusterhoft, K. Hamberg, J.H. Hegemann, B. Obermaier, L.A. Urrestarazu, R. Aert, K. Albermann et al. 1997. The nucleotide sequence of Saccharomyces cerevisiae chromosome XIV and its evolutionary implications. Nature (Suppl.) 387: 93-98.

Pozos, T.C., I. Sekler, and M.S. Cyert. 1996. The product of $\mathrm{HUM} 1$, a novel yeast gene, is required for vacuolar $\mathrm{Ca}^{2+/} \mathrm{H}^{+}$ exchange and is related to mammalian $\mathrm{Na}^{+} / \mathrm{Ca}^{2+}$ exchangers. Mol. Cell. Biol. 16: 3730-3741.

Rao, A., C. Luo, and P.G. Hogan. 1997. Transcription factors of the NFAT family: regulation and function. Annu. Rev. Immunol. 15: 707-747.

Rothstein, R. 1991. Targeting, disruption, replacement, and allele rescue: Integrative DN A transformation in yeast. Methods Enzymol. 194: 281-301.

Rudolph, H.K., A. Antebi, G.R. Fink, C.M. Buckley, T.E. Dorman, J. LeVitre, L.S. Davidow, J.I. M ao, and D.T. Moir. 1989. The yeast secretory pathway is perturbed by mutations in PMR1, a member of a Ca ${ }^{2+}$ ATPase family. Cell 58: 133-145. 
Matheos et al.

Sambrook, J., E.F. Fritsch, and T. Maniatis. 1989. Molecular cloning, A laboratory manual. Cold Spring Harbor Laboratory Press, Cold Spring Harbor, NY.

Schreiber, S.L. and G.R. Crabtree. 1992. The mechanism of action of cyclosporin A and FK506. Immunol. Today 13: 136142.

Sherman, F., J.B. Hicks, and G.R. Fink. 1986. Methods in yeast genetics. Cold Spring Harbor Laboratory Press, Cold Spring Harbor, NY.

Sikorski, R.S. and P. Hieter. 1989. A system of shuttle vectors and yeast host strains designed for efficient manipulation of DNA in Saccharomyces cerevisiae. Genetics 122: 19-27.

Sorin, A., G. Rosas, and R. Rao. 1997. PMR1, a Ca ${ }^{2+}$-ATPase in yeast Golgi, has properties distinct from sarco/endoplasmic reticulum and plasma membrane calcium pumps. J. Biol. Chem. 272: 9895-9901.

Sprague, G.F., Jr. and J.W. Thorner. 1992. Pheromone response and signal transduction during the mating process of Saccharomyces cerevisiae. In The molecular and cellular biology of the yeast Saccharomyces: Gene expression (eds. E.W. Jones, J.R. Pringle, and J.R. Broach, pp. 657-744. Cold Spring Harbor Laboratory Press, Cold Spring Harbor, NY.

Stathopoulos, A.M. and M.S. Cyert. 1997. Calcineurin acts through the CRZ1/TCN1-encoded transcription factor to regulate gene expression in yeast. Genes $\&$ Dev. (this issue).

Stillman, D.J., A.T. Bankier, A. Seddon, E.G. Groenhout, and K.A. N asmyth. 1988. Characterization of a transcription factor involved in mother cell specific transcription of the yeast HO gene. EMBO J. 7: 485-494.

Supek, F., L. Supekova, H. N elson, and N. N elson. 1996. A yeast manganese transporter rel ated to the macrophage protein involved in conferring resistance to mycobacteria. Proc. Natl. Acad. Sci. 93: 5105-5110.

Tanida, I., A. Hasegawa, H. Iida, Y. Ohya, and Y. Anraku. 1995. Cooperation of calcineurin and vacuolar $\mathrm{H}^{+}$-ATPase in intracellular $\mathrm{Ca}^{2+}$ homeostasis of yeast cells. J. Biol. Chem. 270: 10113-10119.

Wallis, J.W., G. Chrebet, G. Brodsky, M. Rolfe, and R. Rothstein. 1989. A hyper-recombination mutation in S. cerevisiae identifies a novel eukaryotic topoisomerase. Cell 58: 409-419.

Wieland, J., A.M. Nitsche, J. Strayle, H. Steiner, and H.K. Rudolph. 1995. The PMR2 gene cluster encodes functionally distinct isoforms of a putative $\mathrm{Na}^{+}$pump in the yeast plasma membrane. EMBO J. 14: 3870-3882.

Withee, J.L., J. Mulholland, R. Jeng, and M.S. Cyert. 1997. An essential role of the yeast pheromone-induced $\mathrm{Ca}^{2+}$ signal is to activate calcineurin. Mol. Biol. Cell 8: 263-277.

Ye, R.R. and A. Bretscher. 1992. Identification and molecular characterization of the calmodulin-binding subunit gene (CMP1) of protein phosphatase 2B from Saccharomyces cerevisiae. An $\alpha$-factor inducible gene. Eur. J. Biochem. 204: 713723. 


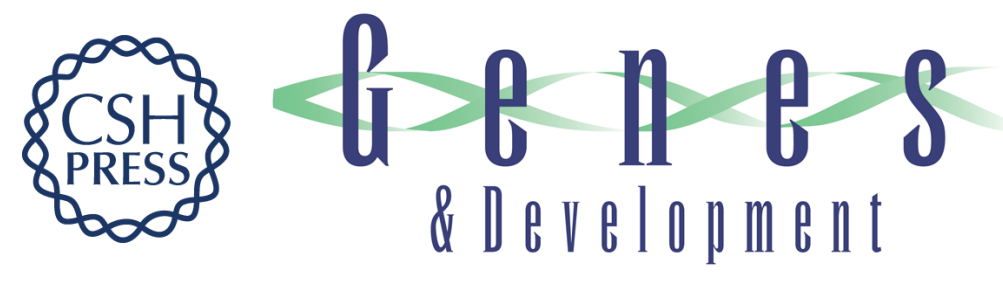

\section{Tcn1p/Crz1p, a calcineurin-dependent transcription factor that differentially regulates gene expression in Saccharomyces cerevisiae}

Dina P. Matheos, Tami J. Kingsbury, U. Salma Ahsan, et al.

Genes Dev. 1997, 11:

Access the most recent version at doi:10.1101/gad.11.24.3445

References This article cites 65 articles, 32 of which can be accessed free at:

http://genesdev.cshlp.org/content/11/24/3445.full.html\#ref-list-1

License

Email Alerting Receive free email alerts when new articles cite this article - sign up in the box at the top Service right corner of the article or click here.

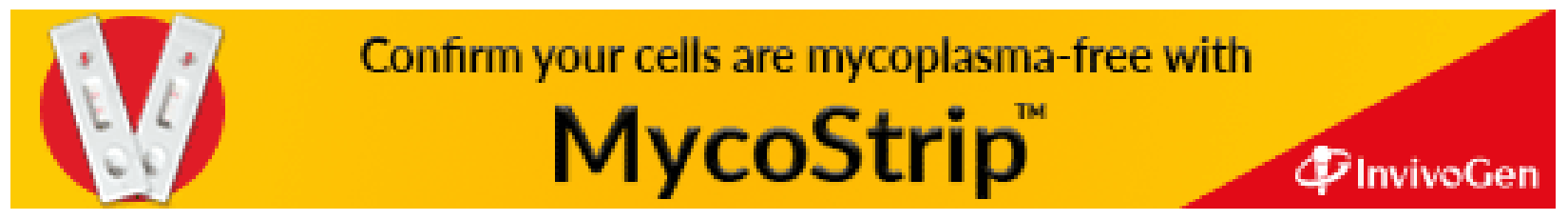

